\title{
EDITORIAL
}

\section{El rol del odontólogo en tiempos de COVID-19}

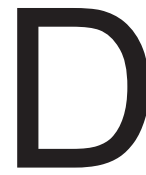
esde el primer caso reportado en el Perú el 6 de marzo de 2020; al 4 de octubre, se han confirmado oficialmente 828,169 con 32,742 fallecidos. En Tacna, tenemos 18,000 casos confirmados con 658 fallecidos.

La OMS recomienda postergar los servicios esenciales ordinarios de salud bucodental -que suelen incluir revisiones, limpiezas y tratamientos preventivos- hasta que disminuya lo suficiente la tasa de contagios de la COVID-19. Sin embargo el cuidado de la salud bucodental es de gran importancia.

Desde nuestro punto de vista, no ha sido acertado separar a los odontólogos de la actividad clínica rutinaria por los riegos de una potencial transmisión por lo que se tenía escasa documentación semiológica a nivel de la cavidad oral lo que implicaría, por un lado, algunas lesiones orales pudieran ser expresión clínica de la infección por SARS-Cov-2, y por otro, que los pacientes deban ser evaluados con un examen oral completo para diagnosticar posibles lesiones y relacionarlas con la COVID-19. Esto cobra importancia porque sabemos que el receptor de la enzima convertidora de angiotensina 2, al que se une el SARS-CoV-2 para poder entrar en la célula huésped, se expresa altamente en las células epiteliales, especialmente en la lengua, en comparación con los tejidos orales o gingivales de la cavidad oral.

La hipogeusia y la disgeusia son los síntomas principales que se han descrito en pacientes con COVID-19. Además, se han reportado manifestaciones orales de aspecto herpetiforme y otras lesiones de la cavidad oral. Sin embargo, se tiene un escaso número de reportes. Podría significar que las manifestaciones en mucosa oral son poco frecuentes, pero también puede significar que muchos pacientes que han padecido la enfermedad, y eventualmente hayan tenido manifestaciones orales, no fueron evaluados por odontólogos para su diagnóstico.

En este contexto, consideramos que cobra relevancia el incorporar a los odontólogos en la evaluación rutinaria de signos y síntomas que se pudieran presentar a nivel de la cavidad oral en pacientes que han sido diagnosticados positivos en el test de RT-PCR para determinar si efectivamente las manifestaciones orales reportadas forman parte de la semiología de la COVID-19, o si, corresponden más bien a distintas entidades patológicas, que pudieran estar favorecidas por una respuesta inmune a la infección en mención. 
Actualmente, algunos equipos de atención primaria de salud, están incorporando la evaluación de la salud oral en el seguimiento de las personas diagnosticadas con COVID-19 por profesionales odontólogos entrenados adecuadamente para ello.Así, determinaremos si el SARS-CoV-2 es capaz de colonizar e infectar la mucosa bucal (infección oral) y si las mucosas orales y secreciones asociadas son capaces de transmitir el SARS-CoV-2 (vía de contagio oral), y en consecuencia surge un tercer aspecto: ¿cuál es la relación entre COVID-19 y la práctica dental?

Sabemos que, hasta hoy, no hay reportes que describan las condiciones orales de pacientes con COVID-19, la posibilidad biológica existe, por lo que los odontólogos debemos estar alertas ante esta situación. Los reportes que tenemos hasta ahora carecen de homogeneidad, aleatoriedad y repetición, lo que dificulta la decisión sobre los enfoques y acciones que sean las más apropiadas para controlar su transmisión y limitar las posibles consecuencias. 